Discussion Paper No. 02-57

\title{
The Prospects of Capital Markets in Central and Eastern Europe
}

Jens Köke and Michael Schröder

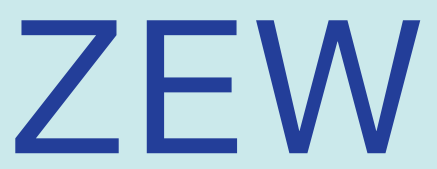

Zentrum für Europäische Wirtschaftsforschung GmbH

Centre for European Economic Research 
Discussion Paper No. 02-57

\title{
The Prospects of Capital Markets in Central and Eastern Europe
}

\author{
Jens Köke and Michael Schröder
}

Download this ZEW Discussion Paper from our ftp server:

ftp://ftp.zew.de/pub/zew-docs/dp/dp0257.pdf

Die Discussion Papers dienen einer möglichst schnellen Verbreitung von neueren Forschungsarbeiten des ZEW. Die Beiträge liegen in alleiniger Verantwortung der Autoren und stellen nicht notwendigerweise die Meinung des ZEW dar.

Discussion Papers are intended to make results of ZEW research promptly available to other economists in order to encourage discussion and suggestions for revisions. The authors are solely responsible for the contents which do not necessarily represent the opinion of the ZEW. 


\section{Non-Technical Summary}

The picture of the securities exchanges and financial sectors in CEE countries is still relatively unfavorable. The CEE securities exchanges - with the only exception of the Warsaw Stock Exchange - are, in comparison with their western counterparts, underdeveloped and less important for the domestic economies in general and for corporate finance in particular. Markets for derivatives exist only in Poland and Hungary. The trade in derivatives is particularly active in Poland which emphasizes the leading role of the Polish stock market in the whole region.

The analysis of the sources of corporate finance shows that the role of the stock and bond markets is currently very unimportant both compared to western countries and in absolute terms. For Poland we investigate the corporate finance using micro data for all companies listed at the Warsaw Stock Exchange. We find that listed companies differ significantly from not listed companies as the capital market plays a more important role as a source of finance.

The CEE securities exchanges are under pressure for several reasons. The most severe reason for the long term is the almost negligible usage of securities exchanges as source of finance by private companies. We evaluate different possible forms of (international) organization of CEE exchanges that could ensure future success of the exchanges and improve the situation for private companies. In particular we investigate a stand-alone solution, the creation of a pan CEE-exchange and different forms of alliances with western exchanges. We find that a good strategy of CEE exchanges would be to join alliances with Western European exchanges, and at best, to join altogether the same western exchange. A stronger international integration of the exchanges would also improve the integration of CEE companies into international capital markets. 


\title{
The Prospects of Capital Markets in Central and Eastern Europe
}

\author{
Jens Köke \\ Mannheim Research Institute for the Economics of Aging (MEA) \\ Michael Schröder \\ Centre for European Economic Research (ZEW)
}

\begin{abstract}
The picture of the securities exchanges and financial sectors in CEE countries is still relatively unfavorable. The CEE securities exchanges - with the only exception of the Warsaw Stock Exchange - are, in comparison with their western counterparts, underdeveloped and less important for the domestic economies in general and for corporate finance in particular. The CEE securities exchanges are under pressure for several reasons and should change their form of (international) organization to ensure future success. Stronger international integration of the exchanges could also improve the integration of CEE companies into international capital markets.
\end{abstract}

JEL Classification: G2, G3, O16, P2

Key Words: Securities Exchanges, Corporate Finance, Central and Eastern Europe

\section{Corresponding address:}

Michael Schröder

Centre for European Economic Research (ZEW)

P. O. Box 1034 43, D-68034 Mannheim, Germany

Tel.: ++49/621/1235-140, Fax: -223

schroeder@zew.de 


\section{Introduction*}

The securities exchanges of Central and Eastern Europe (CEE) are relatively small emerging markets. The largest market among them - the Warsaw Stock Exchange is comparable in size and market turnover to the smallest Western European exchange - the Vienna Stock Exchange. Most of the other CEE stock exchanges such as Tallinn, Riga or Bratislava are still in their infancy and belong to the smallest exchanges in the world. Taken as a whole, the CEE stock markets currently account for no more than $0.2 \%$ of the world stock market capitalization.

The world-wide market downturn since 2000 has affected the CEE exchanges in terms of market capitalization and trading volume as all other exchanges in the world. The effects, however, are felt much more at the CEE exchanges and raises the question whether these exchanges can be important for the CEE economies and particularly for corporate finance in these countries.

In this study we concentrate on the possible future developments of CEE securities exchanges and capital markets. Section 2 provides a detailed assessment of the current status of CEE capital markets. We analyze the major characteristics of stock and bond markets as well as the market for derivatives and investigate the role of institutional investors which is a particularly important group of investors for the development of financial markets. Section 3 evaluates the role of CEE capital markets for corporate finance. We analyze the sources of finance of all CEE companies. In a second step we investigate in detail the sources of finance of Polish non-financial companies listed at the Warsaw Stock Exchange using firm-level data. As a result of this section we can evaluate the use of publicly issued instruments (stocks and bonds) for corporate finance. Section 4 discusses future prospects of CEE securities exchanges. As a result we make a proposal for an optimal form of organization for CEE exchanges which could satisfy the needs of the different interest groups involved. Section 5 concludes.

\section{Current Status of CEE Securities Markets}

To assess the current stage of development of CEE securities markets (stocks, bonds and derivatives), we look at these markets from various perspectives and compare them with selected Western European markets.

We thank our discussant Eva Thiel, OECD, and other participants of the EIB conference „The financial integration of an enlarged EU: Banking and capital markets", held at the European Investment Bank in Luxembourg at January 17, 2001, for helpful comments and suggestions. All remaining errors and mistakes are ours. 


\subsection{Stock Markets}

Table 1 gives an overview of important characteristics of CEE stock and bond markets for the year 2000 and compares these markets to some Western European exchanges. The table shows that the CEE stock exchanges are still relatively small. In absolute size, only the Warsaw Stock Exchange (WSE) is comparable to the smallest Western European exchange - the Vienna Stock Exchange. All other CEE stock exchanges do not only show low market capitalization, they are also relatively unimportant for the economy. This can be seen from the relation of market capitalization to GDP (column 3). Whereas for most of the western exchanges stock market capitalization is well above $50 \%$, the stock markets in Central and Eastern Europe have a capitalization of only $17 \%$ or $18 \%$ (median) relative to GDP. This means that only a small fraction of the total value of CEE companies is traded at the stock exchanges. It is remarkable that the stock markets of Portugal and Greece have developed very well in the last years. There is now a large gap between these two still developing - stock markets and the CEE stock markets.

Table 1: Major Characteristics of CEE Stock and Bond Markets, 2000

\begin{tabular}{|c|c|c|c|c|c|c|}
\hline & \multicolumn{5}{|c|}{ Stock Markets (Domestic Companies) } & \multirow{3}{*}{$\begin{array}{c}\text { Bond Markets } \\
\text { Capitalization } \\
\text { In bn. US-\$ } \\
\text { (in } \% \text { of GDP) }\end{array}$} \\
\hline & \multicolumn{3}{|c|}{ Market Capitalization } & \multicolumn{2}{|c|}{ Market Turnover $^{2}$} & \\
\hline & Bn. US-\$ & $\begin{array}{l}\text { Thereof: } \\
\text { Foreign } \\
\text { Investment }{ }^{1}\end{array}$ & $\begin{array}{c}\text { In } \% \text { of } \\
\text { GDP }\end{array}$ & Bn. US-\$ & $\begin{array}{c}\text { In } \% \text { of } \\
\text { Capitalization }\end{array}$ & \\
\hline Czech Rep. & 9.7 & $30.9 \%$ & $19.2 \%$ & 6.7 (TSV) & $69.0 \%$ & $5.2(10.1 \%)$ \\
\hline Estonia & 1.8 & $27.8 \%$ & $40.5 \%$ & 0.31 (TSV) & $17.2 \%$ & $0.04(1 \%)$ \\
\hline Hungary & 11.9 & $25.0 \%$ & $26.1 \%$ & 12.1 (TSV) & $101.6 \%$ & $9.2(20.2 \%)$ \\
\hline Latvia & 0.56 & $7.1 \%$ & $7.9 \%$ & 0.27 (REV) & $48.2 \%$ & $0.46(6.5 \%)$ \\
\hline Lithuania & 1.6 & $8.0 \%$ & $14.2 \%$ & 0.20 (TSV) & $12.5 \%$ & $0.39(3.5 \%)$ \\
\hline Poland & 31.4 & $16.7 \%$ & $18.9 \%$ & 19.3 (TSV) & $65.1 \%$ & $17.9(10.8 \%)$ \\
\hline Slovak Rep. & 0.44 & $31.9 \%$ (1999) & $2.3 \%$ & 0.54 (TSV) & $122.7 \%$ & $2.2(7.0 \%)$ \\
\hline Slovenia & 3.1 & $4.8 \%$ & $17.4 \%$ & 0.92 (TSV) & $29.7 \%$ & $1.1(6.2 \%)$ \\
\hline Austria & 29.9 & $49.3 \%$ & $15.5 \%$ & 9.6 (TSV) & $32.1 \%$ & $114.1(59.1 \%)$ \\
\hline Germany & $1,270.2$ & $30.0 \%$ & $66.6 \%$ & 2,119.8 (TSV) & $166.9 \%$ & $\begin{array}{c}2,076.5(1999) \\
(108.9 \%)\end{array}$ \\
\hline Greece & 107.5 & -- & $89.6 \%$ & 94.2 (TSV) & $87.6 \%$ & $\begin{array}{c}79.5(1999) \\
(66.3 \%)\end{array}$ \\
\hline Portugal & 60.7 & $31.2 \%$ & $56.7 \%$ & 54.9 (TSV) & $90.4 \%$ & $49.0(45.8 \%)$ \\
\hline UK & $2,612.2$ & $37.8 \%$ & $187.1 \%$ & $\begin{array}{l}4,558.7 \\
\text { (REV) }\end{array}$ & $174.5 \%$ & $\begin{array}{c}1,423.7 \\
(101.9 \%)\end{array}$ \\
\hline
\end{tabular}

Notes: ${ }^{1}$ Foreign investment $=$ international investment position, liabilities, equity securities (International Financial Statistics, IMF, line $79 \mathrm{ldd}$ ) as \% of stock market capitalization. ${ }^{2} \mathrm{TSV}$ counts only transactions which pass through the trading system or the trading's floor, REV counts all transactions under supervision by the market authority (off- and on-market). REV figures are not directly comparable to TSV figures and are usually much larger by construction. Sources: IMF, national central banks, International Federation of Stock Exchanges (FIBV) (2001), national stock exchanges. 
Another important characteristic of stock markets is liquidity, which is often measured as the ratio of market turnover to market capitalization (Table 1, column 5). This ratio tells how often the total value of stocks is turned over on average during a year. A high ratio indicates that the market is relatively liquid. This is particularly important for institutional investors with usually large order sizes. With the exception of Austria the Western European stock markets have a turnover ratio of $90 \%$ to $170 \%$. Particularly the three Baltic exchanges show very low liquidity. The other CEE stock markets have surprisingly high turnover ratios. Although the economic relevance of these markets is rather limited, the degree of trading activity seems to be comparable to western exchanges.

Examining the recent development of CEE stock markets provides another perspective, but the conclusions are similar (Table 2). The number of stocks listed at the Warsaw Stock Exchange has increased continuously since 1995. In contrast, in the Czech Republic, Hungary and the Slovak Republic the number of listed firms has stagnated or even decreased. The picture is similar regarding market capitalization: Warsaw shows a continuously increasing size of the stock market whereas the other three markets show stagnation or a considerable decrease.

Table 2: Development of Stock Markets 1995-2000

\begin{tabular}{|c|c|c|c|c|c|c|}
\hline & 1995 & 1996 & 1997 & 1998 & 1999 & 2000 \\
\hline \multicolumn{7}{|c|}{ Number of Domestic Companies Listed: } \\
\hline Czech Republic & 54 & 82 & 91 & 92 & 74 & 57 \\
\hline Hungary $^{1}$ & 42 & 44 & 47 & 53 & 64 & 58 \\
\hline Poland $^{1}$ & 65 & 83 & 143 & 198 & 221 & 225 \\
\hline Slovak Republic ${ }^{2}$ & 15 & 14 & 10 & 10 & 8 & 7 \\
\hline \multicolumn{7}{|c|}{ Market Capitalization (in \% of GDP): } \\
\hline Czech Republic & $20.0 \%$ & $26.7 \%$ & $24.4 \%$ & $19.3 \%$ & $22.6 \%$ & $19.2 \%$ \\
\hline Hungary & $5.8 \%$ & $12.2 \%$ & $35.2 \%$ & $29.4 \%$ & $35.9 \%$ & $26.1 \%$ \\
\hline Poland & $3.7 \%$ & $6.2 \%$ & $9.1 \%$ & $13.0 \%$ & $19.9 \%$ & $18.9 \%$ \\
\hline Slovak Republic & $6.5 \%$ & $6.4 \%$ & $6.9 \%$ & $3.2 \%$ & $2.4 \%$ & $2.3 \%$ \\
\hline
\end{tabular}

Notes: Statistics for market capitalization and trading volume exclude stocks traded in the unregulated free market. The data include only domestic companies. ${ }^{1}$ The data for Poland and Hungary include also the regulated free market. ${ }^{2}$ The data for the Slovak Republic include the official market only. Source: International Federation of Stock Exchanges (FIBV)(2001), national stock exchanges.

The analysis of foreign demand for CEE assets gives an indication for the attractiveness of CEE stock markets for foreign investors. Column 2 of Table 1 measures the value of stock market capitalization that is held by foreigners. These figures are calculated using the international investment position in equity securities which are documented in the International Financial Statistics (IMF, line 79 ldd). 
They measure the total value of foreign equity holdings at the end of the year relative to stock market capitalization. As some equity holdings are part of foreign direct investments, the foreign equity holdings may to some degree underestimate the true holdings by foreigners. Four CEE countries - the Czech Republic, Estonia, Hungary and the Slovak Republic - exhibit a foreign investment ratio that is comparable to western countries. For Poland, the foreign stock holdings are significantly lower but still much higher than in Latvia, Lithuania and Slovenia. Taking the foreign investment ratio as an indicator of the attractiveness of CEE stock markets, we find that those CEE countries are attractive to foreigners for which liquidity and market capitalization are comparably high. Figures on the inflow of portfolio capital (for stocks and bonds) broadly confirm this result (Table 3). Other reasons might be the institutional development of the securities markets and the protection of property rights (see Garibaldi et al. (2001)).

Table 3: The Structure of Foreign Capital Inflows, Bn. US-\$, Average of 1995-1999

\begin{tabular}{lccccc}
\hline & Equities & Bonds & $\begin{array}{c}\text { Portfolio Investment } \\
\text { (\% of GDP) }\end{array}$ & $\begin{array}{c}\text { Other } \\
\text { Investment }\end{array}$ & $\begin{array}{c}\text { FDI } \\
\text { (\% of GDP) }\end{array}$ \\
\hline Czech Rep. & 3.43 & 1.83 & $5.26(1.9 \%)$ & 13.58 & $13.1(4.8 \%)$ \\
Estonia & 0.57 & 0.22 & $0.79(3.6 \%)$ & 1.59 & $1.5(6.8 \%)$ \\
Hungary & 3.11 & 1.78 & $4.89(2.1 \%)$ & 1.22 & $12.9(5.6 \%)$ \\
Latvia & 0.04 & 0.21 & $0.25(0.9 \%)$ & 2.32 & $1.8(6.4 \%)$ \\
Lithuania & 0.07 & 0.69 & $0.76(1.7 \%)$ & 0.63 & $2.0(4.5 \%)$ \\
Poland & 3.31 & 1.69 & $5.00(0.7 \%)$ & 7.56 & $26.7(3.8 \%)$ \\
Slovak Rep. & 0.13 & 0.29 & $1.42(1.4 \%)$ & 5.10 & $1.7(1.7 \%)$ \\
Slovenia & 0.06 & 1.30 & $1.36(1.4 \%)$ & 1.97 & $1.2(1.3 \%)$ \\
\hline
\end{tabular}

Notes: FDI = Foreign Direct Investment. Source: International Financial Statistics, IMF.

Overall, the CEE stock markets are still underdeveloped and economically unimportant compared to western stock markets. The markets in the Czech Republic, Hungary and Poland are the best developed markets among the CEE countries. These three markets also have a market liquidity that is comparable to Western European stock markets. The least developed CEE markets are those of the Slovak Republic, Latvia and Lithuania. The recent decline in going public activity darkens the perspectives for some CEE markets considerably. During 1999 and 2000 virtually no company went public in the Czech and Slovak Republics, and none during 2000 in Hungary. Partially this might be due to the global downturn in stock markets in 2000, but it also suggests a lack of interest in these markets. 


\subsection{Bond Markets}

To examine the size of bond markets, we first look at total capitalization (last column of Table 1). These figures should be interpreted with caution because a large part - sometimes even the majority- of bonds are traded over the counter (OTC). Typically, OTC traded bonds are included neither in capitalization nor in turnover figures of bond markets. Therefore, Table 1 gives only an approximate picture. We find that the CEE bond markets are - in absolute and relative size - small compared to Western European bond markets. With the exception of the Slovak Republic, the bond markets are even much smaller than the CEE stock markets, but this can probably be explained by the large amount of OTC trade.

A different approach to examining the importance of CEE debt markets is the analysis of all debt securities outstanding. This approach has the advantage that not only publicly traded securities are examined and that it can distinguish between domestic and international debt securities. According to the definition of the Bank for International Settlements, domestic debt securities are bonds issued by local issuers in local currency. International debt securities are (a) bonds issued by local residents in the domestic or international market, denominated in foreign currency or (b) bonds issued by international issuers (corporations or other institutions such as the EBRD or the EIB) issuing in domestic markets, denominated in local or foreign currency.

Table 4 shows the amount of outstanding domestic and international debt securities as of December 2000. The Czech Republic has the (relative to GDP) largest domestic debt market, measured in terms of total outstanding debt securities $(46.1 \%$ of GDP), Hungary ranks second (35.5\%) and Poland third (20.3\%). In absolute terms, the Polish market for domestic debt securities is the largest with $\$ 33.9$ billion in 2000. This result suggests that the OTC market in Poland is indeed significant. Compared to major western economies these markets are nevertheless small. We also find that the markets for corporate non-financial bonds are insignificant with the exception of the Czech market. However, corporate bond markets are also underdeveloped in most of the western countries considered here, with the notable exceptions of Portugal and the UK.

Regarding international debt securities, there is a significant market in Hungary and the Slovak Republic, reaching $23.0 \%$ and $15.2 \%$ of GDP, respectively. But the largest fraction of these international debt securities is issued by the public sector, thus contributing little to corporate finance. Only in Poland international debt securities are primarily issued by non-financial corporations. 
Table 4: Outstanding Debt Securities (in \% of GDP) as of December 2000 by Type of Security

\begin{tabular}{lcccccc}
\hline & \multicolumn{3}{c}{ Domestic Securities } & \multicolumn{3}{c}{ International Securities } \\
\hline & Financial & Corporate & Total $^{1}$ & Financial & Corporate & Total $^{1}$ \\
\hline Czech Republic & $5.5 \%$ & $5.3 \%$ & $46.1 \%$ & n.a. & n.a. & n.a. \\
Hungary & n.a. & $1.5 \%$ & $35.5 \%$ & $0.4 \%$ & $0.4 \%$ & $23.0 \%$ \\
Poland & n.a. & $0.0 \%$ & $20.3 \%$ & $0.3 \%$ & $2.3 \%$ & $3.3 \%$ \\
Slovak Republic & n.a. & n.a. & n.a. & $1.0 \%$ & $1.0 \%$ & $15.2 \%$ \\
Germany & $49.7 \%$ & $1.3 \%$ & $90.2 \%$ & $39.9 \%$ & $6.7 \%$ & $47.7 \%$ \\
Spain & $5.3 \%$ & $4.8 \%$ & $59.0 \%$ & $14.8 \%$ & $6.2 \%$ & $27.2 \%$ \\
United Kingdom & $20.1 \%$ & $13.0 \%$ & $63.3 \%$ & $24.2 \%$ & $14.8 \%$ & $39.9 \%$ \\
Portugal & $16.1 \%$ & $9.6 \%$ & $61.7 \%$ & $15.8 \%$ & $2.5 \%$ & $32.1 \%$ \\
Austria & $30.6 \%$ & $1.7 \%$ & $79.5 \%$ & $28.5 \%$ & $2.6 \%$ & $49.4 \%$ \\
\hline
\end{tabular}

Notes: ${ }^{1}$ Total outstanding debt securities volume encompasses financial debt securities, corporate debt securities as well as public debt securities. The last category is omitted from this table. n.a. $=$ not available. Sources: Bank for International Settlements (2001).

In sum, the CEE bond markets are generally still small compared to western markets. In particular, the markets for corporate debt securities are underdeveloped. Only in the Czech Republic, there is a significant and active primary market for domestic corporate debt securities, and only in Poland, there is a significant primary market for international corporate debt securities.

\subsection{Derivatives Markets}

Budapest and Warsaw are currently the only CEE exchanges offering derivatives for trading. Prague obtained the permission to organize derivatives trading in August 2001. In this section we give a brief overview to the derivatives markets in Hungary and Poland, regarding the type of securities, trading value and some remarks on the market's recent historical development.

The Budapest Stock Exchange has started trading futures contracts in April 1995: index futures on the BUX, the main stock index in Budapest, interest futures with terms between three months and three years, as well as currency futures on the US Dollar, the Euro, the Japanese Yen, the British Pound and the Swiss Franc. Since 1998 also trading in derivatives on individual stocks is possible. In September 2001, a total of 26 Hungarian stocks represented the potential underlying. The futures contracts' maximum maturity is 12 months, and for the BUX future it is 21 months.

The Warsaw Stock Exchange has started trading derivatives in January 1998: index futures on the WIG20, the main stock index in Warsaw, interest futures as well as currency futures on the US Dollar and the Euro. In August 2000, an index future on the TechWIG, the stock market segment for young high-tech firms, has been added. And since January 2001, futures on three individual stocks are available. The futures 
contracts maximum maturity is nine months, and for the individual stocks it is three months.

Additionally, there is a standardized options market in Budapest. This market has started in February 2000. During the year 2000, 132 options on three different stocks and 40 options on the BUX have been traded. The turnover during 2000 was 9,747 contracts $(1,231$ for stocks and 8,516 for the index). In Warsaw, there is an OTC market for 87 warrants on stocks, 26 on indices and four on bonds. However, trading in the warrants is almost negligible.

Table 5 gives a brief summary of recent historical turnover volume for derivatives. We find that both in Hungary and in Poland futures trading show a jump-start, increasing exponentially after the introduction of derivatives trading. However, futures trading on the BUX peaked in 1998 and since then declined steadily. In contrast, futures trading on the WIG20 continues to increase in volume since its introduction in 1998, reaching a value of 17.1 bn US\$ over the period of January to September 2001. This compares to 0.8 bn US\$ for futures trading on the BUX.

Table 5: Turnover Value of Derivatives Trading (in Million US\$), 1995-2001

\begin{tabular}{|c|c|c|c|c|c|c|c|}
\hline & 1995 & 1996 & 1997 & 1998 & 1999 & 2000 & $2001^{1}$ \\
\hline \multicolumn{8}{|l|}{ Hungary: } \\
\hline BUX & 4.2 & 322.0 & 5376.0 & 8313.2 & 4718.5 & 3126.1 & 822.1 \\
\hline Currencies & 29.6 & 731.2 & 1803.3 & 4542.7 & 96.0 & 101.1 & 60.9 \\
\hline Stocks & -- & -- & -- & 239.5 & 570.4 & 1563.5 & 823.9 \\
\hline Interest & 47.0 & 197.7 & 401.3 & 591.5 & 51.9 & 6.6 & 0.0 \\
\hline \multicolumn{8}{|l|}{ Rates } \\
\hline \multicolumn{8}{|l|}{ Poland: } \\
\hline WIG20 & -- & -- & -- & 0.2 & 1.5 & 9041.6 & 17143.7 \\
\hline Currencies & -- & -- & -- & -- & 0.1 & 129.51 & 233.68 \\
\hline Stocks & -- & -- & -- & -- & -- & 0.0 & 157.8 \\
\hline
\end{tabular}

Notes: ${ }^{1}$ January-September 2001. Source: Budapest Stock Exchange (2001), Warsaw Stock Exchange (2001).

Similarly, in Budapest trading value on interest derivative products sharply declined after 1998. In 2001, trading in interest futures even came to a halt. One reason for this decline is probably the improvement in macroeconomic conditions and stabilizing interest rates. In contrast, the performance of futures contracts with a single underlying stock looks encouraging as its turnover value continuously increased and slightly exceeded turnover value of the BUX futures contracts in 2001. Regarding trading of currency futures, in Hungary as well as in Poland, their volume is small compared to the futures on the indices or individual stocks.

Overall, the derivatives markets of CEE countries, as far as they exist, appear to be quite active. Currently, in Poland the market for stock index futures is the most active in terms of trading volume; the markets for futures on currencies and 
individual stocks are much smaller. In Hungary, most trading takes place in the markets for index futures and futures on individual stocks. However, since 1998 total trading volume in the Budapest derivatives market has declined considerably. This stands in sharp contrast to the successful start of the derivatives market in Poland.

\subsection{Institutional Investors}

For western capital markets, assets under management of institutional investors (such as mutual funds, pension funds and insurance companies) have grown tremendously in the past two decades (Blommestein, 1998). In addition, it is often argued that institutional investors play an important role in improving corporate governance (Del Guercio and Hawkins, 1999). In the following we try to assess to what extent institutional investors are already present in Central and Eastern Europe.

Table 6 shows the financial assets under institutional management, scaled by GDP. Among the CEE countries, assets under institutional management are the most significant in the Czech Republic with $20.3 \%$ of GDP in 1999, and this ratio does not vary much over the past decade. One reason for this large institutional involvement is the Czech voucher privatization scheme, which ultimately made the (mostly publicly owned) investment funds the new owners of the privatized companies. Institutional assets are smaller in Hungary (10.7\% of GDP) and in Poland (4.2\%), but in both countries institutional ownership is steadily growing at high speed. For example, in both countries it doubled in value during the four-year period 1995-1998.

Table 6: Financial Assets Under Institutional Management (in \% of GDP), 1992-2000

\begin{tabular}{lccccccccc}
\hline & 1992 & 1993 & 1994 & 1995 & 1996 & 1997 & 1998 & 1999 & $2000^{\mathrm{P}}$ \\
\hline Czech Rep. & n.a. & $22.8 \%$ & $17.3 \%$ & $17.8 \%$ & $21.4 \%$ & $19.0 \%$ & $16.8 \%$ & $20.3 \%$ & n.a. \\
Hungary & $2.5 \%$ & $2.8 \%$ & $3.9 \%$ & $4.4 \%$ & $6.1 \%$ & $7.5 \%$ & $8.9 \%$ & $10.7 \%$ & $12.8 \%$ \\
Poland & $0.0 \%$ & $0.6 \%$ & $1.9 \%$ & $1.5 \%$ & $2.0 \%$ & $2.6 \%$ & $3.2 \%$ & $4.2 \%$ & $5.4 \%$ \\
Germany & $34.0 \%$ & $38.9 \%$ & $41.3 \%$ & $45.3 \%$ & $50.6 \%$ & $58.7 \%$ & $66.1 \%$ & $76.8 \%$ & $79.7 \%$ \\
Spain & $21.9 \%$ & $29.3 \%$ & $32.3 \%$ & $33.4 \%$ & $44.3 \%$ & $56.0 \%$ & $66.5 \%$ & $65.4 \%$ & $62.1 \%$ \\
United & 131.3 & 163.0 & 143.8 & 164.0 & 173.4 & 195.5 & 203.6 & 226.7 & n.a. \\
Kingdom & $\%$ & $\%$ & $\%$ & $\%$ & $\%$ & $\%$ & $\%$ & $\%$ & \\
Portugal & $18.3 \%$ & $27.5 \%$ & $29.8 \%$ & $38.3 \%$ & $43.2 \%$ & $53.4 \%$ & $48.7 \%$ & $50.8 \%$ & n.a. \\
Austria & $24.1 \%$ & $28.5 \%$ & $30.4 \%$ & $35.0 \%$ & $40.3 \%$ & $47.0 \%$ & $54.6 \%$ & $68.4 \%$ & n.a. \\
\hline
\end{tabular}

Notes: ${ }^{\text {P }}$ Data for 1999 and 2000 are provisional. No data are available for the Slovak Republic. Sources: IMF (2001), OECD (2001).

Compared to major western economies, institutional investment in CEE economies is still small. In Germany and the UK, institutional investors own financial assets worth $76.8 \%$ and $226.7 \%$ of GDP in 1999 , respectively. Smaller European countries such as Austria, Portugal or Spain have experienced fast growing institutional 
investment over the past few years. Hence, it is reasonable to assume a similar development of institutional investment for the countries of Central and Eastern Europe. Factors driving this development are - compared to western standards - a still young insurance sector, and in case of Hungary and Poland the reform of social security. In Hungary a pension reform introduced private pension funds in 1997, and in Poland in 1999. Recent statistics demonstrate that the Polish pension funds owned assets of over 2.6 bn Zloty ( $0.4 \%$ of GDP) in the year 2000, and the Hungarian pension funds about $13 \%$ of GDP (National Bank of Poland, 2001; National Bank of Hungary, 2001).

An analysis of the composition of financial assets reveals that only a small fraction is invested in stocks. Among the CEE countries it is the largest for Poland (15\%) and the Czech Republic (21\%). The latter figure may be explained by the ownership-taking role of investment funds in the Czech privatization process. Institutional investors in Hungary appear to behave risk-averse, investing over three quarters of financial assets in government bills or bonds, thereby financing the government deficit. Thus, the Hungarian institutional investors play only an insignificant role in corporate finance. According to the National Bank of Hungary (2001), private and voluntary pension funds hold the largest fraction of risky assets among the institutional investors, with about $14 \%$ in stocks. Compared to institutional investors in the UK, where $65 \%$ are invested in stocks, institutional investment in the stock market in the CEE economies is small. But as shown in Table 6, there is a clear trend towards a larger institutional engagement, particularly for those countries that implemented social securities reforms.

\subsection{Key Regulatory Characteristics of CEE Stock Markets}

Securities exchanges influence the functioning of the exchanges by setting listing requirements and fees for admission, maintenance and trading. This section gives an overview of the major qualitative and quantitative rules for the CEE exchanges and those Western European exchanges where stocks or depositary receipts of CEE companies are listed. Tables $7 \mathrm{a}-7 \mathrm{c}$ show that the rules and fees are qualitatively similar across the different exchanges, but there are also some large differences concerning the details.

In general, the CEE securities exchanges have much higher minimum standards for market capitalization, both in the official and in the regulated markets than Frankfurt or London. The highest minimum levels can be found at the Newex (New Europe Exchange) which aimed at becoming a central exchange for CEE stocks. In addition to criteria for the free float, which are almost the same for all exchanges compared, most of the CEE exchanges have requirements concerning the number of shareholders to guarantee a minimum of liquidity. The Newex established so-called 
liquidity providers that have to set bid and ask quotes to provide a basis for active trading.

Companies listed in the official market are required to publish their financial information according to the International Accounting Standards (IAS). Therefore this information is published in an internationally comparable way. In addition, most exchanges (except Bratislava) require quarterly company reports. But only in Bratislava, Warsaw and at the Newex the financial information have to be published in English. These relatively high standards impose additional costs on the listed companies. But as the exchanges and companies in Central and Eastern Europe have to build up confidence to attract domestic and foreign investors these rules probably have a positive impact because they lower the information costs of investors.

At the regulated markets (also called parallel or secondary markets) the listing requirements are a compromise between the strictly regulated official markets and the almost fully unregulated free markets. Nevertheless, Bratislava and Prague stock exchanges as well as the Newex require IAS for the financial statements of the companies. Therefore at these three exchanges international investors also have relatively low information costs concerning accounting figures.

The fixed and variable fees for admission and maintenance, and the fee structures are very different across exchanges. But the fees do not seem to be excessive and therefore should not be an obstacle for going public. The fees at the CEE exchanges are also comparable to those for listing depositary receipts at the London Stock Exchange.

At most CEE exchanges only a minority of the companies are listed at the official markets. Only at the Warsaw Stock Exchange, the number of listings at the official market (in 2000: 131 companies $=62,1 \%$ of all listings) is significantly higher than at the other two market segments. At most of the other CEE exchanges listings at the unregulated free markets dominate, e.g. in the Czech Republic at the end of 2000 $55 \%$ of all listings have been at the free market, in Latvia $65.1 \%$, in the Slovak Republic 95.6\% and in Slovenia 74\%. With the exception of Warsaw these listings impose no costs on the companies. But due to the lack of regulation these firms are hardly of any interest to foreign and domestic investors. International investors therefore have to concentrate on the few stocks of the official markets and partly the stocks of the regulated market. The concentration of listings in the free market segments are probably due to overly strict listing requirements. Also the fee structures could give some incentive for a listing in the free market, as there are with the exception of Warsaw - no fees in the free market segment. 


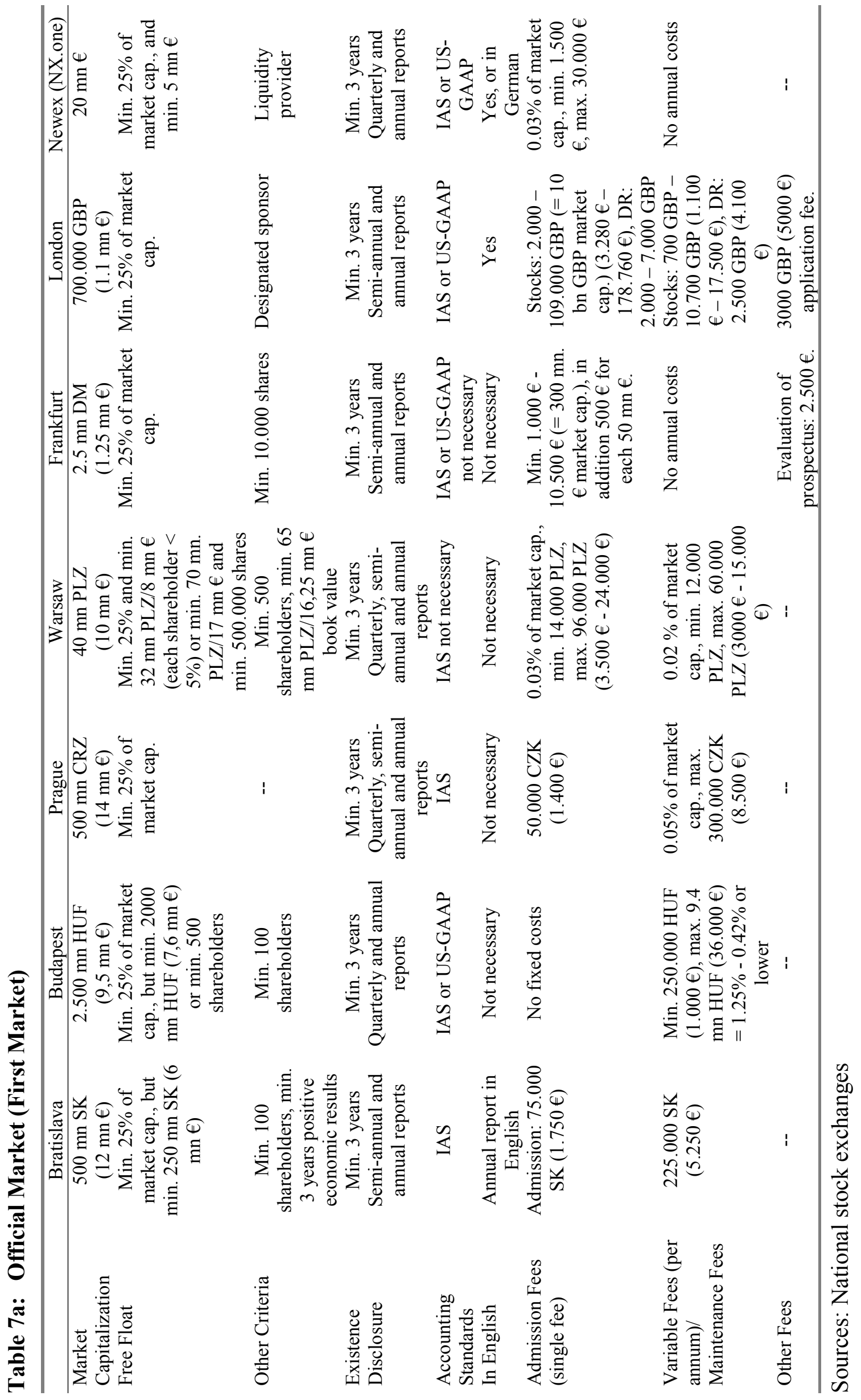




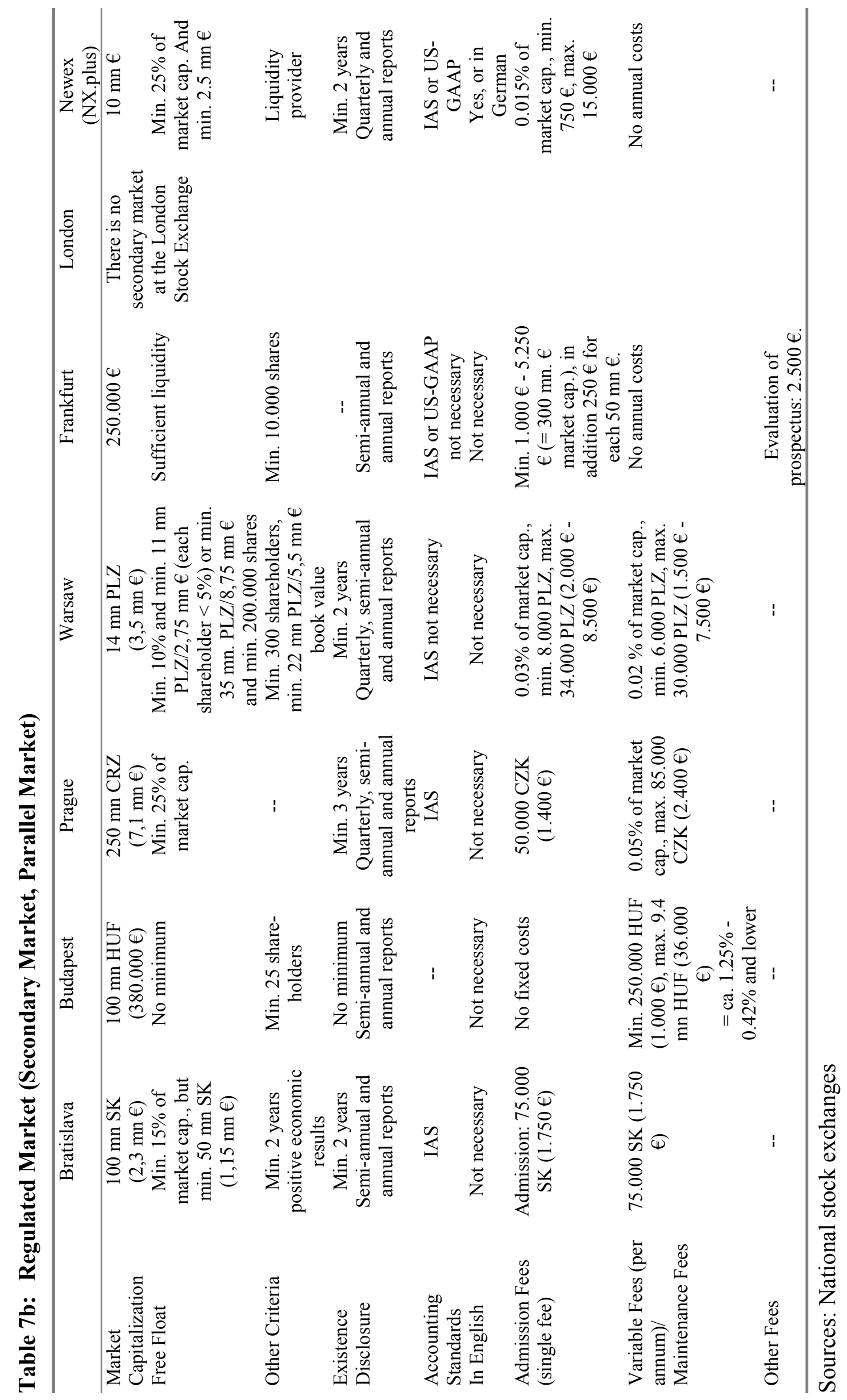




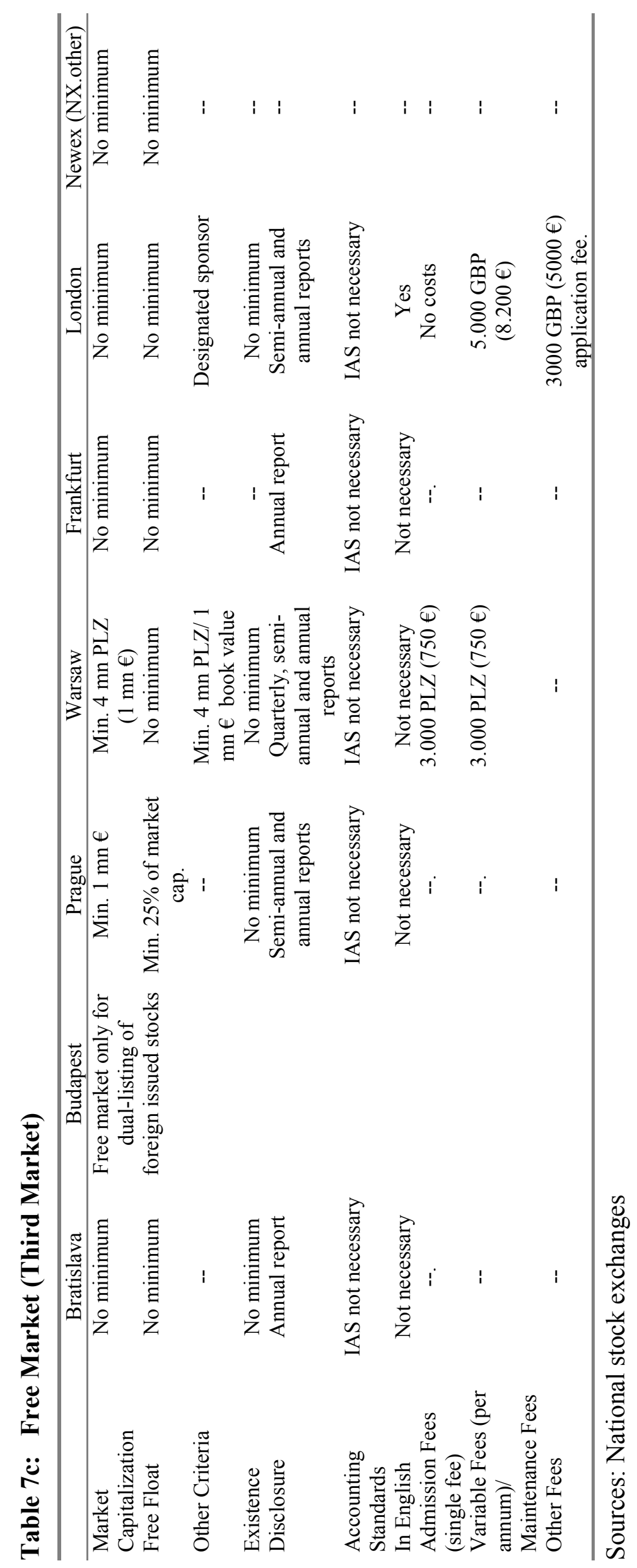


In summary, the regulatory rules and the fee structures of the CEE stock exchanges are rather different. Even the classification of the different market segment is not fully comparable across exchanges. A harmonization of the regulatory rules could significantly reduce the information costs of investors. The listing requirements of the official market segments are relatively high compared to Western European exchanges. These strict requirements may be one reason for the relatively small number of listings in this segment. As there is also a high concentration of listings in the unregulated free market segments, most of the CEE stock markets have the disadvantage of inducing high information costs to investors. Thus, these exchanges are relatively unattractive for institutional investors, particularly from abroad. The only exception seems to be the Warsaw Stock Exchange.

\section{The Role of Capital Markets for Corporate Finance}

In this section, we try to evaluate to what extent firms from Central and Eastern Europe use capital markets for financing corporate investment. First we give an overview to the sources of corporate finance using information on bank credit as well as bond and share issues. The major advantage of this top-down approach is that it uses data aggregated on the country level and therefore covers all domestic firms. It also allows to compare the sources of finance between Eastern and Western European countries. In a second step, we make use of detailed firm-level data. In a case-study framework we evaluate the sources of finance for all non-financial corporations listed on the Warsaw Stock Exchange, the largest CEE stock market.

\subsection{Sources of Finance}

To obtain a comprehensive picture of the funding sources for corporate investment in the CEE economies, we collect information from a variety of data sources. The aim is to investigate to what extent investment in non-financial enterprises is funded by credit, bond issues and stock issues. We distinguish between three kinds of credit (credit by resident banks, credit by non-resident banks and inter-company loans), two kinds of bonds (domestic bonds and international bonds) ${ }^{1}$ and share issues. ${ }^{2}$ Credit by resident banks is defined as the change in the credit stock provided by the resident banking system to non-financial enterprises. Credit by non-resident banks is defined as the change in the loans taken abroad by "other sectors", a sub-item of the

1 Domestic debt securities are bonds issued by local issuers in local currency. International debt securities are (a) bonds issued by local residents in the domestic or international market, denominated in foreign currency or (b) bonds issued by international issuers (corporates or other institutions such as the EBRD or the EIB) issuing in domestic markets, denominated in local or foreign currency. See Bank for International Settlements (2001).

2 Below we also distinguish between capital raised through already listed firms (seasoned public offerings) and capital raised by newly listed firms (initial public offerings). 
countries' international liabilities. ${ }^{3}$ Intercompany loans are loans of the parent company to a (non-financial) subsidiary. Complying to the methodology of the IMF, these loans are part of foreign direct investment (FDI). Funds from securitized debt can be originated from the issue of domestic bonds, which are mostly local-currency denominated, and from the issue of international bonds, which are mostly foreigncurrency denominated. The Bank for International Settlements (BIS) provides information on the net issue value of both types of securities, separately for the corporate, financial and public sector. Since we are interested in the funding sources of the non-financial corporate sector, we focus on corporate sector debt securities. Finally, funds raised by share issues, both from initial and secondary public offerings, are reported by the International Federation of Stock Exchanges (FIBV). Table 8 reports the ratio of funds obtained from each of these sources to gross fixed capital formation, which is calculated as the average for the years 1999 and 2000 to smooth short-run fluctuations.

For the CEE economies, we find that the sum of capital raised by credits from resident and non-resident banks, intercompany loans as well as domestic and international debt securities varies greatly by country. It is the largest for Hungary with $41.9 \%$ of gross fixed capital formation, the second largest for Poland with $23.6 \%$ and much smaller for the Czech Republic (10.3\%) and the Slovak Republic $(4.0 \%)$. These results suggest that Hungarian non-financial firms fund a comparatively large fraction of corporate fixed investment by raising capital externally. In contrast, firms from former Czechoslovakia obviously have severe difficulties in raising funds externally and are likely to be constrained to using internally generated funds (e.g. retained earnings) for financing investment. The comparison with Germany, Spain and Portugal shows that Hungary has already reached a western level of external funding.

Table 8 also provides evidence on the relative weight of each of the funding sources. For Hungary and Poland, credits by resident banks are the most important source of funding, credit by non-resident banks the second most important. In both countries, more than three quarters of all external funds are raised in the form of bank credit. For Portugal, this dominance of funding by credit is similar, and to a lesser extent also for Spain. For the Czech Republic, financing by credit from domestic banks is even negative during the years 1999-2000. This signals severe credit constraints. High real interest rates - indicating the cost of capital - cannot be blamed for the lack of borrowing since real lending rates are only 100-150 basis points above the EU level (Deutsche Bank Research, 2001). Rather, this shortfall appears to be a result of excessive lending in early years of transition, followed by a credit crunch and extreme risk aversion after the collapse of several financial institutions.

3 Using credits taken by „other sectors“ as a proxy for borrowing by non-financial enterprises assumes that credits taken abroad by domestic households is negligible. 
Table 8: Sources of Funding (in \% of Gross Fixed Capital Formation), Average for 1999-2000

\begin{tabular}{lccccccr}
\hline & $\begin{array}{c}(1) \\
\text { Credits } \\
\text { from } \\
\text { Resident } \\
\text { Banks }\end{array}$ & $\begin{array}{c}(2) \\
\text { Credits } \\
\text { from Non- } \\
\text { Resident } \\
\text { Banks }\end{array}$ & $\begin{array}{c}\text { Intercom- } \\
\text { pany } \\
\text { Loans }\end{array}$ & $\begin{array}{c}(4) \\
\text { Domestic } \\
\text { Debt } \\
\text { Securities }\end{array}$ & $\begin{array}{c}(5) \\
\text { International } \\
\text { Debt } \\
\text { Securities }\end{array}$ & $\begin{array}{c}(6) \\
\text { Sum of } \\
(1)-(5)\end{array}$ & $\begin{array}{c}(7) \\
\text { IPO/SPO }\end{array}$ \\
\hline Czech & $-2.6 \%$ & $4.1 \%$ & $4.4 \%$ & $4.4 \%$ & n.a. & $10.3 \%$ & $1.1 \%$ \\
Republic & & & & & & & \\
Hungary & $18.6 \%$ & $15.4 \%$ & $5.6 \%$ & $1.4 \%$ & $0.9 \%$ & $41.9 \%$ & $7.6 \%$ \\
Poland & $11.1 \%$ & $6.7 \%$ & $3.6 \%$ & $0.0 \%$ & $2.2 \%$ & $23.6 \%$ & $1.3 \%$ \\
Slovak & $0.7 \%$ & $-2.4 \%$ & $3.0 \%$ & n.a. & $2.6 \%$ & $4.0 \%$ & $0.0 \%$ \\
Republic & & & & & & & \\
Germany & $6.6 \%$ & $1.8 \%$ & $14.3 \%$ & $2.3 \%$ & $11.4 \%$ & $36.4 \%$ & $5.2 \%$ \\
Spain & $44.6 \%$ & $11.7 \%$ & $2.6 \%$ & $4.5 \%$ & $10.3 \%$ & $73.6 \%$ & $67.8 \%$ \\
Portugal & $36.7 \%$ & $-0.9 \%$ & $3.4 \%$ & $2.6 \%$ & $4.4 \%$ & $46.2 \%$ & $36.3 \%$ \\
\hline Source: Ban & & & & & & & \\
\end{tabular}

Source: Bank for International Settlements (2001), national central banks, IMF (2001).

Czech firms are partially able to circumvent these credit constraints by accessing the market for debt securities. We find that Czech firms raise a larger amount of capital (relative to gross fixed capital formation) by issuing debt securities than firms from Hungary or Poland. This finding is consistent with the result from Section 2.2, which shows that the Czech corporate bond market is the most developed among the CEE economies in terms of size and trading. Comparing the Czech bond market with western markets, we find that only the Spanish market for corporate debt securities is similarly large. In contrast, firms from Germany and Spain are able to raise a much larger amount of capital by issuing international debt securities than firms from the CEE countries. One reason for this finding could be that for CEE firms the costs of issuing on foreign bond markets are too high compared to the domestic market (e.g. due to larger risk premia or higher transaction costs); another reason could be that issuing in foreign currency is regarded as too risky due to increasing exchange rate volatility.

Additionally, the last column of Table 8 presents the amount of capital raised by newly or already listed companies via initial or secondary public offerings, again relative to gross fixed capital formation. We find that the largest amount of capital has been raised at the Budapest Stock Exchange, whereas raising funds via public stock offerings has been rather limited in the other three CEE countries. Note that extremely large amounts of capital are raised during 1999-2000 in Portugal and Spain. Partially this reflects a catch-up process for the respective stock markets. Taking Germany as the benchmark for the CEE countries, public stock issues do not contribute significantly to corporate finance in Poland, the Czech Republic and the Slovak Republic. 
In sum, compared to western countries only Hungarian firms finance a similarly large fraction of gross fixed capital formation externally (about 50\%), i.e. without relying on internally generated funds such as retained earnings. ${ }^{4}$ This fraction is much lower for Poland (25\%), the Czech Republic (11\%) and the Slovak Republic $(4 \%)$. Whereas these ratios are only a very rough approximation for the sources of finance since they are based on highly aggregated data for each economy, the observed significant difference between these four CEE countries should be reliable. Among external funds, for Hungary and Poland the dominant sources of funding are domestic as well as foreign credits. In contrast, during the period of 1999-2000 Czech and Slovak firms appear to have had major difficulties in financing investment by (particularly domestic) credit. Overall, usage of capital market funding is very limited: Financing by stock issues is the highest in Hungary (7.6\% of gross fixed capital formation), and financing by domestic bond issues is the highest in the Czech Republic (4.4\%).

\subsection{Case Study: Sources of Finance in Poland}

To complement our top-down approach from Section 3.1, we now examine the sources of corporate finance in a bottom-up type manner. Specifically, we examine all corporations listed at the Warsaw Stock Exchange over the period 1994-2000. The main reason for selecting Poland is that the Polish stock market is the largest and the best developed among the CEE markets. In addition, disclosure requirements are very strict, requiring firms to submit quarterly information to shareholders according to the International Accounting Standards (IAS). We investigate the financial statements for all non-financial corporations over the period 1994-2000 to obtain a detailed picture of the sources of finance available for investment.

Table 9 distinguishes between three sources of funding: internal funds (measured as net profit plus interest payments, taxes and depreciation), asset divestiture (measured as inflows from investment activity, especially from the sale of fixed and intangible assets and from the sale of marketable securities) and external funds (measured as inflows from financial activity, especially loans taken and issues of bonds and own shares). During the period 1998-2000, external funds play the dominant role among the three sources of gross finance. On average, for small and large firms more than $50 \%$ of gross funds are external funds. Internal funding contributes much less to total funding, with on average $14.0 \%$ for small firms and $24.7 \%$ for large firms. Not negligible are also the funds obtained from asset divestitures. A comparison with the period $1994-1997$ shows that in this period internal funding constituted the main source of funding, with $57.0 \%$ for small firms and $42.6 \%$ for large firms. Hence,

4 As a rough approximation, the fraction of internal finance can be calculated as $100 \%$ less the fraction observed for all external sources of finance including IPO/SPO. 
funding by internally generated funds declined sharply over the recent five years. In contrast, funding by asset divestitures became significantly more important. These findings are consistent with the notion that increasing product market competition eroded profit margins, thereby reducing the ability for internal funding. At the same time, Polish firms appear to have adapted their corporate structures by spinning off some assets or to have reduced free cash flow, as reflected in the increasing role of funds generated from asset sales. Overall, in recent years the largest volume of funds is, on average, not any longer generated internally but raised externally.

Table 9: Gross Sources of Funding of all Polish companies (non-financial) listed at the Warsaw Stock Exchange, 1994-2000

\begin{tabular}{lcccc}
\hline & \multicolumn{2}{c}{$1994-1997$} & \multicolumn{2}{c}{$1998-2000$} \\
\hline & Small Firms & Large Firms & Small Firms & Large Firms \\
Internal Funds & $57.0 \%$ & $42.6 \%$ & $14.0 \%$ & $24.7 \%$ \\
Asset Divestiture & $9.3 \%$ & $17.5 \%$ & $30.3 \%$ & $24.3 \%$ \\
External Funds & $3.7 \%$ & $39.9 \%$ & $55.7 \%$ & $51.1 \%$ \\
Total & $100 \%$ & $100 \%$ & $100 . \%$ & $100 . \%$ \\
Number of obs. & 380 & 382 & 344 & 345 \\
\hline
\end{tabular}

Notes: All reported statistics are calculated at the mean. Gross sources of funding are measured as follows: internal funds (net profit + interest payments + taxes + depreciation), asset divestiture (inflows from investment activity, especially sale of fixed and intangible assets and sale of marketable securities) and external funds (inflows from financial activity, especially loans taken and issues of bonds and own shares). Statistics are calculated as the average for each of the four subsamples. Large/small firms are firms with total assets above/below the year-specific sample median. Source: Notoria Serwis S.A.

Table 10 investigates the inflows from financial activity more closely, essentially by splitting them into the contribution by loans taken, bonds and shares issued, and other sources. We find that the largest fraction of externally raised funds consists of new loans, with about 70\% during the years 1998-2000. The largest part of these loans are short-term (i.e. with maturity less than one year). Funding by bond issues is much smaller. This difference in the type of debt financing indicates that loans are still more popular and probably easier accessible than bond issues. At the Warsaw Stock Exchange, only one corporate bond is traded since April 2000. This suggests that Polish stock corporations are able to issue international bonds which are not traded on the WSE. But clearly, the probability to make use of bond finance is positively related to firm size. Concerning the role of equity finance, share issues contribute to $18.4 \%$ for small firms and $9.4 \%$ for large firms. Hence, stock issues appear to be more relevant for smaller firms. This suggests that stock issues are used as a source of finance typically by smaller and probably younger firms, for example in the course of an initial public offering. Larger and probably older firms make less use of public stock offerings, although the fraction of $9.4 \%$ is still significant. 
Table 10: Composition of Gross External Funding of all Polish companies (non-financial) listed at the Warsaw Stock Exchange, 1994-2000

\begin{tabular}{lcccc}
\hline & \multicolumn{2}{c}{$1994-1997$} & \multicolumn{2}{c}{$1998-2000$} \\
\hline & Small Firms & Large Firms & Small Firms & Large Firms \\
Loans Taken & $56.3 \%$ & $63.4 \%$ & $69.8 \%$ & $71.5 \%$ \\
thereof Short-term & $42.6 \%$ & $45.0 \%$ & $56.1 \%$ & $54.7 \%$ \\
Bonds Issued & $3.2 \%$ & $8.1 \%$ & $5.0 \%$ & $13.6 \%$ \\
thereof Short-term & $2.1 \%$ & $5.9 \%$ & $4.5 \%$ & $10.7 \%$ \\
Shares Issued & $29.1 \%$ & $22.1 \%$ & $18.4 \%$ & $9.4 \%$ \\
Other & $11.4 \%$ & $6.4 \%$ & $6.7 \%$ & $5.4 \%$ \\
Total & $100 . \%$ & $100 . \%$ & $100 . \%$ & $100 . \%$ \\
Number of obs. & 380 & 382 & 344 & 345 \\
\hline
\end{tabular}

Notes: Composition of gross external funding is measured as follows: loans taken (long- and shortterm loans taken), bonds issues (long- and short-term bonds issued), shares issued (inflows from issue of own shares). 'Short-term' means maturity is less than one year. Statistics are calculated as the mean for each of the four subsamples (median reported in parentheses). Large/small firms are firms with total assets above/below the year-specific sample median. Source: Notoria Serwis S.A., own calculationsEinführung

A comparison with the respective figures for 1994-1997 reveals that loan and bond financing has become more common, and equity financing less common. One reason for the decline in equity financing by stock issues is certainly the decline in going public activity, which in turn reflects the slowdown in privatization activity. The increase in bond financing versus loan financing indicates that Polish stock corporations are not restricted to loan finance. To the contrary, the use of debt securities has increased by more than $50 \%$ when comparing the fractions reported in Table 10 for the periods of 1994-1997 and 1998-2000.

Overall, this case study illustrates the funding sources for corporate investment using micro data for all non-financial corporations listed at the Warsaw Stock Exchange. We are able to confirm the dominance of loan finance, as documented in Section 3.1. Hence, the dominance of loan funding appears to be similar for listed and non-listed Polish firms. But the results of this section indicate that internal funding plays a much smaller role for listed firms than for all other firms in the economy. Similarly, for listed firms we are not able to confirm that finance by the issue of debt or equity securities plays an almost insignificant role, as documented in Section 3.1 for the entire Polish economy. For large listed firms, these two sources of funding contribute to about a quarter of all externally raised funds, which in turn make up for about $50 \%$ of gross funding. Therefore, listed Polish corporations appear to differ substantially in terms of sources of finance from other Polish firms because the capital market plays an important role in their financing patterns. Nevertheless, loan finance is still the dominant source of funding also for listed firms. This stands in contrast to the situation of non-listed firms, which predominantly rely on internally generated funds. 


\section{Future Prospects for CEE Securities Exchanges}

In this section we first describe and evaluate the current form of international organization of CEE securities exchanges, and second, we analyze in detail the options for future changes and give a recommendation for an optimal form of international organization.

\subsection{The Current Organization of CEE Securities Exchanges and Options for the Future}

The results of the last two chapters have shown a relatively unfavorable picture for the CEE stock and bond markets. The CEE securities markets are under pressure for several reasons. First, the supply of new assets by domestic companies is very small as can be seen, for example, by the decomposition of sources of funding of CEE companies shown in Table 8 (column 7). IPO and SPO are almost negligible for most CEE countries, except perhaps Hungary. This restricts the future potential for growth in market capitalization and turnover of the stock exchanges. Second, the current world-wide downturn in stock prices and turnover could damage the CEE exchanges severely as the very low market size and liquidity are further reduced to a level where the existence of some CEE exchanges is under question.

The CEE securities exchanges have developed different strategies to improve their situation. Most of these strategies focus on alliances with western exchanges. The three Baltic exchanges Tallinn, Riga and Lithuania have created the so-called Baltic list which aims at harmonizing the trade in 15 blue chip stocks of that area. The Baltic exchanges also intend to soon join the Nordic Stock Exchange (Norex) which is an alliance of the four Northern European exchanges in Copenhagen, Oslo, Stockholm and Iceland. ${ }^{5}$ On the other side, the Helsinki Exchange (HEX) holds 50\% of the equity of the Tallinn Exchange. The HEX is also linked to the German Stock Exchange. This relatively complex picture of international connections of the three Baltic exchanges shows that these exchanges see the solution to their problems in joining stronger partners.

This is also the strategy of the Warsaw Stock Exchange which has signed a letter of intent with the London Stock Exchange in July 1999 to strengthen future cooperation. The Warsaw Stock Exchange, however, has also contacts with Euronext. The probability of joining Euronext has increased with the introduction of the WARSET trading system which was developed by the SBF-Paris Bourse for the Warsaw exchange. The Prague Stock Exchange has signed a Memorandum on Mutual Cooperation with the London Stock Exchange in mid-2000. The other CEE

The negotiations between the Norex and the three Baltic exchanges have come to a (temporary?) halt since May 2001. 
exchanges - Budapest, Ljubljana and Bratislava - still try to continue business on their own.

The landscape of international security exchanges currently undergoes rapid changes. Most experts expect and recommend a consolidation that should further decrease the operating and trading costs; see Lee (2002) and McAndrews and Stefanadis (2002). Schmiedel (2001) finds that European exchanges are operating at a cost level that is $20-25 \%$ above an efficient benchmark. Consolidation is not restricted to exchanges but includes also important services such as cross-border clearing and settlement; see Giovannini Group (2001). Another driving force of stock exchange consolidation is the integration process in the European Union; see the proposals of the Committee of Wise Men (2001). The CEE exchanges are no active players in this consolidation game. Rather, they will have to find an optimal solution under the restriction of the future world-wide changes.

According to Lee (2002) the international exchanges face the following trilemma: 1 . try to do business successfully on their own, 2. build a virtual exchange by establishing remote linkages among some exchanges and 3. create a larger typically regional exchange by merging with other exchanges. Lee is relatively skeptical on the success of the second option as he believes that changes in the economic environment will often lead to incentives to leave the alliance. Instead, he expects a merger to be a more stable scenario.

As Malkamäki (2000) shows, there are significant economies of scale only concerning the processing of trades. In other business units he finds economies of scale only for "very large exchanges". Hence, the CEE exchanges should try to cut costs by creating a common trading platform with other exchanges.

Claessens et al. (2202) investigate the reasons for the migration of companies in emerging economies to international financial centers. Exchanges in emerging economies face the problem that when the financial sector of the economy is successfully developed the companies have increased opportunities to access international exchanges. Particularly the largest companies will find it attractive to go abroad. This causes a reduction of liquidity for the domestic stock exchanges and reduces the chances of these exchange to develop successfully. As the authors do not find a comparative advantage of stock exchanges in emerging economies "in offering capital raising, listing and trading services", they recommend not to develop fully-fledged stock markets in emerging economies. Instead they propose to improve the financial infrastructure such as shareholder rights and the legal system. As a consequence, domestic companies should have easier access to foreign exchanges and more international capital could be attracted. In addition, the authors recommend to link regional stock markets with each other and with larger foreign exchanges. Then domestic investors should have cheaper and easier access to 
foreign assets. As smaller companies in emerging economies are often not able to raise capital abroad, the credit market and the market for venture capital should also be developed.

Pagano et al. (2001a, 2001b) analyze the reasons for companies to list abroad. They find some reasons that significantly influence the success of international stock exchanges to attract foreign companies: liquid exchanges with low trading costs, high accounting standards and good shareholder protection. Exchanges with these characteristics should be particularly attractive for investors and thus lead to low costs of funding equity for the companies. Nevertheless, accounting standards should not be too stringent as they induce extra costs to the listed companies. This last finding of Pagano et al. can be an explanation for the fact that only a small fraction of CEE companies is listed in the top trading segment whereas most companies prefer to be traded in the free market.

From the point of view of the costs of financial services for domestic companies and investors, McAndrews and Stefanadis (2002) propose an increase in competition among international stock exchanges. According to the authors the governments should create regulatory standards and remove obstacles to full competition in this field. As a consequence the costs of corporate and private finance should significantly decrease.

To sum up, the main results of the aforementioned studies are: first, the financial sector infrastructure and particularly the legal system in CEE countries should have a high international standard to attract foreign capital and to enable domestic companies to have access to foreign financial sectors, second, the CEE stock exchanges should be linked with each other and with larger international exchanges, third, these linkages or alliances will be particularly cost-saving when they concentrate on a common trading platform and common trading standards, and fourth, a higher degree of domestic and international competition within the financial sector can help to reduce the financing costs of domestic companies and investors.

\subsection{An optimal Solution for the Organization of CEE Securities Exchanges}

The stock exchanges of Central and Eastern Europe have already begun to analyze new forms of organization which could improve their business in the future. As described in section 4.1 some exchanges are in the process to find an alliance with a Western European stock exchange, the Baltic exchanges have built a regional network and a few exchanges are still trying to develop their own business alone. Besides these three forms of organization there are - at least - two other possible solutions: the CEE exchanges could join an alliance with a western exchange 
altogether instead of single alliances and they could create a pan-CEE stock exchange. The aim of the following reasoning is to evaluate the different forms of organization for the CEE exchanges and to find a solution that could be optimal for investors, issuers and the exchanges themselves.

In the literature on the future global organization of securities exchanges (see e.g. Accenture (2001), Fischer and Kunz (2001), OECD (2001a)) an optimal solution is discussed that has the following characteristics: the exchange is organized as network, trade is fully centralized (common trading platform) and the local exchanges have remote membership to the trading platform and have the major task to offer service to the users of the exchange. Such a concept creates a market with relative high liquidity and harmonized institutional arrangements which should result in relatively low overall costs for investors. This concept can serve as a benchmark for the evaluation of the future options of CEE exchanges.

\section{Option 1: Stand-alone solution}

The stock exchanges of Budapest, Ljubljana and Bratislava are not looking for an alliance with a western exchange and try to do business on their own. But this is probably no viable solution for the long run. In a stand-alone solution the exchange has to bear the full overhead costs. The costs of e.g. a new trading system cannot be shared with other exchanges. Another important problem concerns the standardization of the rules of the exchange (e.g. the listing requirements, trading rules). If the rules are not harmonized with the rules of a larger western exchange foreign investors may find it too costly to accommodate to the rules of a relatively small stock exchange. As a consequence, larger companies will manage to cross-list at a foreign exchange and to use the foreign exchange for raising new capital. This will make it hard to increase market capitalization and liquidity. Therefore the above mentioned three CEE exchanges will be forced to choose a different solution in the long run.

\section{Option 2: Fully fledged CEE exchange}

The CEE exchanges could try to merge and create a pan-CEE exchange. Compared to option 1 this has the advantage of harmonized rules within the group of CEE exchanges and a higher liquidity. But this exchange has also major shortcomings: negotiations among up to eight CEE exchanges should be very difficult as all have different interests, and the new exchange has to build up an own infrastructure which might be very costly. To our knowledge, the CEE exchanges have actually no interest to merge with each other. 


\section{Option 3: Single alliances with western exchanges}

The exchanges in Prague and Warsaw and the three Baltic exchanges try to join an alliance with a western exchange. An alliance or a merger with a larger Western European exchange has several advantages which are mainly the disadvantages of a stand-alone strategy: an alliance can help to share overhead costs, the rules of the CEE exchange are harmonized with the rules of the western partner exchange and third, CEE companies are integrated in a large and liquid capital market.

But there are also some disadvantages when each of the CEE stock exchanges decide to choose a different partner exchange. For the CEE exchange one of the most severe problems is the small capitalization compared to the western partner exchange. For example, the market capitalization of the Warsaw Stock Exchange at the end of 2000 was only $1.4 \%$ of the capitalization of Euronext. Thus, stocks of Polish companies are of little importance for the business strategy and economic performance of Euronext. Polish stocks would also be hardly visible within the stock list of the alliance. Hence companies from CEE countries will still be interested in cross-listings at other exchanges. And investors particularly interested in CEE stocks still have the problem that CEE stocks are listed at many exchanges with different rules and clearing and settlement systems.

\section{Option 4: All CEE stock exchanges choose an alliance with the same western exchange}

For investors, companies from CEE countries and the CEE stock exchanges it might therefore be a superior solution that all or most of the CEE exchanges decide to join an alliance with the same western exchange. In this case the disadvantages of single alliances could be avoided. First, the CEE exchanges altogether are more important in terms of market capitalization. Compared to Euronext their share in the common market capitalization of about $2.6 \%$ would still be relatively small. But joining the Norex this share would be approximately $10 \%$. At least in this latter case the CEE exchanges together should have some influence on the business strategy of the alliance. For the investors the major advantage of this solution would be that all CEE stocks could be traded at the same exchange and as a consequence the cost of information and accommodation with institutional arrangements would be lowest. Issuers, on the other hand, would not have significant incentives to cross-list outside the alliance. Therefore, this solution could guarantee the highest market liquidity. In addition, the CEE stocks could benefit from a high visibility to investors.

Nevertheless, although this solution has many advantages it is not the most probable one. The CEE stock exchanges do not seem to prefer this model but instead try to find an optimal partner exchange in Western Europe on their own. The reason might be an overweight of the interests of the management of the exchanges compared to 
the interests of their clients. In the short term the management could benefit from becoming the only CEE partner of a western exchange because in this case the individual importance is not divided among several CEE exchanges. Another reason is that negotiations among up to eight CEE exchange could easily become too complicate compared to bilateral negotiations between one western and one CEE exchange.

To sum up, for CEE exchanges an alliance or a merger with a western exchange is preferable to the other options (stand-alone solution, pan-CEE exchange). This should also be the best form of organization for the users of the exchanges: CEE companies are integrated in a large and liquid capital market and the investors benefit from the harmonization of regulatory rules and institutional arrangements and relatively low overall transaction costs. Most probable is that CEE exchanges enter single alliances with western exchanges.

\section{Conclusion}

The picture of the securities exchanges and financial sectors in CEE countries is still relatively dark. The stock markets exhibit a low market capitalization - both in absolute terms and relative to GDP - and a low level of liquidity compared to Western European exchanges. The best developed stock exchanges are those of the Czech Republic, Hungary and Poland. Among this group the Polish stock exchange clearly merits a top ranking. The Warsaw Stock Exchange has the highest capitalization, the largest official market segment which is particularly interesting for foreign and institutional investors, and a liquid index future on the blue chip index WIG20 which allows investors to efficiently hedge stock market risk.

Regarding the sources of corporate finance, CEE firms finance the largest fraction of investment internally. Compared to western countries, only Hungarian firms finance a similarly large fraction of gross fixed capital formation externally (about 50\%), i.e. without relying on internally generated funds such as retained earnings. This fraction is much lower for Poland (25\%), the Czech Republic (11\%) and the Slovak Republic (4\%). Closer analysis of the sources of external finance reveals that the largest part is obtained by taking new credits, and a much smaller part by issuing equity or debt securities. Particularly in Hungary and Poland, new credits contribute significantly to financing investment, and particularly in the Czech Republic the issue of domestic debt securities is relevant for corporate finance.

Overall, this dominance of credit finance is confirmed in a case study of all nonfinancial corporations listed at the Warsaw Stock Exchange. We find that in recent years Polish listed firms predominantly rely on credit finance. Compared to earlier years of transition, internal funding has declined significantly. Similarly, finance by equity issues has declined over the period 1994-2000 but still contributes strongly to 
corporate finance. This suggests that the Polish privatization scheme conducted by large-scale sales to strategic investors connected with a going public has benefited the Polish stock market, and the Polish stock market appears to be viable even in times of a slowdown in privatization activity. This finding contrasts with the evidence for the other CEE countries, which recently show a much larger decline in going public activity than Poland.

The CEE stock exchanges have an organization comparable to Western European exchanges. The official markets and partly also the regulated markets have relatively strict listing requirements. Therefore, foreign investors have relatively low information costs at the official market segment. But with the exception of the Warsaw Stock Exchange only a minority of companies is listed at the official market. Usually the unregulated free market has the highest number of listings. This may be due to overly strict listing requirements and high publication standards in the official market segment and partly also the regulated market. As a consequence, foreign investors interested in CEE stocks are mostly restricted to the few stocks listed at the official market segments.

The different regulatory rules and institutional arrangements of the CEE exchanges induce relatively high information costs to investors and together with low liquidity the overall transaction costs are relatively high. This reduces the interest of foreign investors in CEE stocks. The CEE exchanges are also under pressure because domestic companies do hardly use the exchanges to for external funding. The securities exchanges try to escape these problems by joining stronger partners in Western European countries. According to our analysis this is probably the best what the CEE exchanges can do because then the regulatory and institutional rules are the same as in western partner exchanges, the listed companies are fully integrated in a large capital market and for investors the transaction costs are relatively low. Probably most of the CEE exchanges will join an alliance with a western exchange in the next years.

\section{Literature}

Accenture, 2001, Leaving Safe Havens - The Accelerating Evolution of the European Exchange Landscape, http://www.accenture.com $/ \mathrm{xd} / \mathrm{xd}$.asp?it=enWeb\&xd=industries $\% 5 \mathrm{cfinancial} \% 5 \mathrm{ccapital} \%$ 5cprofile two.xml

Bank for International Settlements, 2001, Statistics on Domestic and International Debt Securities Markets, http://www.bis.org. 
Blommestein, H., 1998, The New Financial Landscape and Its Impact on Corporate Governance, in: M. Balling, E. Hennessy and R. O'Brien (ed.s), Corporate Governance, Financial Markets and Global Convergence (Kluwer Academic Publishers, Dordrecht), Chapter XVI.

Bratislava Stock Exchange, 2001, Annual Report, http://www.bsse.sk.

Budapest Stock Exchange, 2001, Annual Report, http://www.bse.hu.

Claessens, S., D. Klingebiel and S. Schmukler, 2002, Explaining the Migration of Stocks from Exchanges in Emerging Economies to International Centres, CEPR Discussion Paper No. 3301, www.cepr.org/pubs/dps/DP3301.asp.

Committee of Wise Men, 2001, Final Report of the Committee of Wise Men on the Regulation of European Securities Markets, http://europa.eu.int/comm/internal_market/en/finances/general/lamfalussyen.pdf

Deutsche Bank Research, 2001, EU Enlargement Monitor: Central and Eastern Europe, http://www.dbresearch.com.

Del Guercio, D. and J. Hawkins, 1999, The Motivation and Impact of Pension Fund Activism, Journal of Financial Economics 52, 293-340.

Fischer, U. and R. Kunz, 2001, Börsenhandel in Europa: Fakten, Trends, Szenarien, Die Bank 11/2001, 756-760.

Garibaldi, P., N. Mora, R. Sahay and J. Zettelmeyer, 2001, What Moves Capital to Transition Countries?. IMF Staff Papers 48 (Special Issue), 109-145.

Giovannini Group, 2001, Cross-Border Clearing and Settlement Arrangements in the European Union, http://europa.eu.int/comm/economy finance/publications/giovannini/clearing1101 en.pdf International Federation of Stock Exchanges (FIBV), 2001, International Statistics on Stock and Bond Markets, http://www.fibv.com.

IMF, 2001, International Financial Statistics, Monthly Issues, Washington: International Monetary Fund.

Lee, R., 2002, The Future of Securities Exchanges, Working Paper, Wharton Financial Institutions Center, The Wharton School, No. 02-14, http://fic.wharton.upenn.edu/fic/papers/02/0214.pdf

London Stock Exchange, 2001, Electronic Information from the Internet, http://www.londonstockexchange.com

Malkamäki, M., 2000, Economies of Scale and Implicit Mergers in Stock Exchange Activities, Working Paper, http://fmg.lse.ac.uk/events/conferences/pastcon/exchanges/papers/malkamaki.pdf 
McAndrews, J. and C. Stefanadis, 2002, The Consolidation of European Stock Exchanges, Current Issues in Economics and Finance 8, Federal Reserve Bank of New York, 1-6.

National Bank of Germany (Deutsche Bundesbank), 2001, Statistical Yearbook, http://www.bundesbank.de.

National Bank of Hungary (Magyar Nemzeti Bank), 2001, Statistical Yearbook, http://www.mnb.hu.

National Bank of Poland (Narodowy Bank Polski), 2001, Statistical Yearbook, http://www.nbp.pl.

National Bank of Portugal (Banco de Portugal), 2001, Statistical Yearbook, http://www.bportugal.pt.

National Bank of Spain (Banco de Espana), 2001, Statistical Yearbook, http://www.bde.es.

National Bank of the Czech Republic (Ceská Národni Banka), 2001, Statistical Yearbook, http://www.cnb.cz.

National Bank of the Slovak Republic (Národná Banka Slovenska), 2001, Statistical Yearbook, http://www.nbs.sk.

New Europe Exchange (NEWEX), 2001, Electronic Information from the Internet, http://www.newex.com.

OECD, 2001, Recent Trends: Institutional Investors Statistics, Financial Market Trends 80, 43-52.

OECD, 2001a, Future Prospects for National Financial Markets and Trading Centres, Financial Market Trends 78, 37-72.

Pagano, M., O. Randl, A. Röell and J. Zechner, 2001a, What makes Stock Exchanges Succeed? Evidence from Cross-Listing Decisions, European Economic Review 45, 770-782.

Pagano, M., A. Röell and J. Zechner, 2001b, The Geography of Equity Listing: Why do Companies list Abroad?, Discussion Paper, forthcoming in the Journal of Finance, http://www.banque-france.fr/gb/fondatio/telechar/papers d/geograph.pdf.

Prague Stock Exchange, 2001, Electronic Information from the Internet, http://www.pse.cz.

Schmiedel, H., 2001, Technological Development and Concentration of Stock Exchanges in Europe, Discussion Paper, Research Department, Bank of Finland, http://www.bof.fi/eng/6 julkaisut/6.1_SPn julkaisut/index.asp?page=tutkimuksia.stm

Warsaw Stock Exchange, 2001, Electronic Information from the Internet, http://www.wse.com.pl. 